\title{
Arbuscular mycorrhiza technology applied to micropropagated Prunus avium and to protection against Phytophthora cinnamomi
}

\author{
C Cordier, A Trouvelot, S Gianinazzi, V Gianinazzi-Pearson * \\ Laboratoire de phytoparasitologie Inra/CNRS, CMSE, Inra, BV 1540, 21034 Dijon cedex, France
}

(Received 30 July 1996; accepted 23 September 1996)

\begin{abstract}
Summary - Two species of arbuscular mycorrhizal (AM) fungi (Glomus intraradices, Glomus caledonium) introduced during post vitro acclimatization were tested for infection development and growth effects in Prunus avium, after transplantation into two types of disinfected or undisinfected neutral soils. Endomycorrhizal plants grew better than nonmycorrhizal plants in both disinfected soils. Growth improvements by either fungus were related to a high level of mycorrhizal colonization. Mycorrhizal effects on $P$ avium plants and mycorrhiza development depended on the soil type. In undisinfected soils containing an infective but inefficient AM fungal population, growth of Prunus was improved by preinoculation with effective AM fungi adapted to the soil type. Moreover, clonal variations in AM development and mycorrhizal responsiveness to Glomus mosseae were observed in three $P$ avium clones. The bioprotective effect of AM was shown in one clone where the presence of $G$ mosseae eliminated the negative impact of Phytophthora cinnamomi on root growth.
\end{abstract}

micropropagated Prunus avium clones / arbuscular mycorrhizal fungi / Phytophthora cinnamomi / plant growth / bioprotection

Résumé - L'endomycorhization de vitroplants de merisiers (Prunus avium L) : son intérêt pour la production et dans la protection vis-à-vis du pathogène Phytophthora cinnamomi. Deux champignons endomycorhizogènes à arbuscules (Glomus intraradices, Glomus caledonium), introduits pendant la période d'acclimatation, ont été testés pour leur pouvoir infectieux et leur effet sur la croissance de plants micropropagés de merisiers (Prunus avium $L$ ) transplantés dans deux différents sols neutres, préalablement désinfectés ou non. Les vitroplants endomycorhizés présentent une meilleure croissance que les plantes témoins sur les deux sols désinfectés. L'importance de l'augmentation de croissance est corrélée à une importante infection mycorhizienne. Cependant, la nature du sol influence l'établissement de la symbiose et son effet sur la croissance des plantes. Sur sols non désinfectés, une mycorhization préalable des plants micropropagés de $P$ avium est bénéfique en utilisant des champignons endomycorhizogènes sélectionnés pour leur efficacité dans ces sols. La réponse à l'infection endomycorhizienne est également fonction du clone de plants micropropagés de merisiers. Une seconde étude a également montré que l'endomycorhization du merisier a un effet bioprotecteur vis-à-vis du champignon pathogène Phytophthora cinnamomi.

merisier micropropagé / champignon endomycorhizogène à arbuscule / Phytophthora cinnamomi / croissance de la plante hôte / bioprotection

\footnotetext{
* Correspondence and reprints
} 


\section{INTRODUCTION}

Micropropagation techniques are applied to the production of many plants from flowers to forest trees, including wild cherry (Prunus avium $L$ ) (Lovato et al, 1996). This procedure suppresses the natural root microflora, including arbuscular mycorrhizal (AM) fungi. AM fungi are known to have beneficial effects on the growth and development of most micropropagated species (Ponders, 1984; Douds and Chaney, 1986; Lovato et al, 1994), through improvement of mineral nutrition, induction of root system modifications (Berta et al, 1995) and increased resistance or tolerance to pathogens (Guillemin et al, 1992; Linderman, 1994). Their omission during micropropagation frequently results in poor development of plants, so that their reintroduction during plant production is important.

In vitro AM have been successfully established in axenically propagated plants of $P$ avium (Pons et al, 1983) and in micropropagated vines (Ravolanirina et al, 1989b). However, Gianinazzi et al (1983) and Lovato et al (1994) showed the importance of post vitro mycorrhiza establishment for improving growth and uniformity of wild cherry. This has also been described for Prunus cerasifera by Fortuna et al (1992) and Berta et al (1995). Maximum benefits from AM require optimum efficiency of mycorrhiza establishment. For this, three major factors must be considered: the moment of mycorrhizal inoculation, the substrate to be used and the choice of AM fungi (Lovato et al, 1996). For example, the weaning period is best for mycorrhizal inoculation of pineapple (Guillemin et al, 1991), vine (Ravolanirina et al, 1989a), ash (Lovato et al, 1994) and $P$ cerasifera (Fortuna et al, 1992). Furthermore, studies of different varieties of pineapple plants (Guillemin et al, 1992) and $P$ cerasifera (Fortuna et al, 1992) showed that growth improvement by AM is closely related to the associated AM fungal strain.

The present paper reports a series of experiments carried out to combine the use of AM with the production of micropropagated $P$ avium. The effects of substrates, fungal strains and plant clones were assessed in order to optimize the beneficial effects of $A M$ as bioregulators and biofertilizers. Furthermore, since AM fungi are also known for their potential bioprotective effects against root pathogens in micropropagated plants (Bärtschi et al, 1981; Bethlenfalway and Linderman, 1992; Guillemin et al, 1994; AzcónAguilar and Barea, 1997), preliminary studies were made on interactions between $A M$ and Phytophthora cinnamomi Rands in $P$ avium.

\section{MATERIALS AND METHODS}

\author{
Plant material \\ Wild cherry (Prunus avium L) clones 227, 4878×2620, \\ $2680 \times 1923$ and cv F12-1 were obtained by microprop- \\ agation and kindly provided by the Unite de \\ Prédéveloppement In Vitro (INRA, Dijon, France).
}

\section{Experiments}

\section{Effects of two species of mycorrhizal fungi and two soil types on growth of $\boldsymbol{P}$ avium clone 227}

Micropropagated plants were transplanted from in vitro into a disinfected ( $\gamma$ irradiated) 2:1:1 mixture of clay loam soil ( $\mathrm{pH}$ 8, 26 ppm Olsen P), calcinated clay (Oil Dry type III-R, Laporte Absorbents Europe, Germany) and grit, containing or not containing inoculum (AM onion roots) of Glomus intraradices (Schenck and Smith) (LPA8) or G caledonium ((Nicol and Gerd) Gerdemann and Trappe (BEG20). Plants were weaned for 5 weeks in multipots $(75 \mathrm{~g})$ and in a constant environment $\left(18^{\circ} / 23^{\circ} \mathrm{C}, 16 \mathrm{~h}\right.$ photoperiod, $300 \mu \mathrm{mol}$ photons $\mathrm{m}^{-2} \mathrm{~s}^{-1}, 70 \%$ relative humidity). Micropropagated plants were then transferred individually to pots containing $400 \mathrm{~g}$ disinfected ( $\gamma$ irradiated) (D) or undisinfected (ND) soil. Two types of silty clay soils, originating from the region of Châtillon-sur-Seine (France) and destinated for $P$ avium plantation, were tested: E1 (pH 6.3, $31.9 \mathrm{ppm}$ Olsen P) and E2 (pH 7.9, $47.6 \mathrm{ppm}$ Olsen $P$ ) containing 4600 and 6600 mycorrhizal propagules/kg soil, respectively, estimated by the most probable number method (Plee, 1986).

Each plant was watered daily with distilled water and weekly with $16 \mathrm{~cm}^{3}$ of nutrient solution (Hayman, 1974). Three months later, plant growth was evaluated by several parameters: plant height $(\mathrm{cm})$, number of leaves, shoot dry mass $(\mathrm{g})$ and stem diameter $(\mathrm{cm})$, and mycorrhizal infection was estimated according to Trouvelot et al (1986).

\section{Comparison of mycorrhizal growth responses in different $\boldsymbol{P}$ avium clones}

Three micropropagated clones (F12-1, 4878x2620, $2680 \times 1923$ ) were transplanted from axenic conditions into $400 \mathrm{~g}$ disinfected soil mix (described in experiment 1 ), containing or not containing leek root fragments colonized by $G$ mosseae (Nicol and Gerd) Gerdemann and Trappe (BEG12), and weaned in a mini-greenhouse (Maxi serre, Bouillard Frères, Saint Germain-enPlain, France). Experiments were carried out under 
similar environmental conditions as in experiment 1. Each plant was watered daily with distilled water and weekly with P/10 Long Ashton solution (Hewitt, 1966). Inoculated and uninoculated plants were harvested at different times and plant growth was evaluated by stem height. Estimation of mycorrhizal colonization was estimated as described earlier.

\section{Interactions between arbuscular mycorrhiza and $P$ cinnamomi in $P$ avium clone $\mathrm{F} 12-1$}

Three-week-old micropropagated plants, inoculated or not with $G$ mosseae, were prepared as in experiment 2. Half of the mycorrhizal and non-mycorrhizal plants were inoculated with $40 \mathrm{~mL}$ of $P$ cinnamomi mycelium suspension. The isolate of $P$ cinnamomi ( $n^{\circ} 070973$ ), kindly provided by SAC (Aberdeen, UK), was grown on $3.9 \%$ potato dextrose agar (PDA) medium (Sigma, Saint-Quentin-Fallavier, France). After 2 weeks, small blocks of pathogen mycelium were macerated in water and the suspension used as inoculum. Plants were grown in a constant environment (see experiment 1) and harvested at 5 or 7 weeks after transplanting (corresponding to 2 or 4 weeks after pathogen inoculation). Fresh shoot and root mass were recorded and mycorrhizal colonization estimated as described earlier.

\section{Statistical analyses}

In all experiments, each treatment comprised five replicates and all data was analyzed using the Stat-ITCF programme. Significant differences were calculated by the Newman-Keuls test at $P<0.01$ and $P<0.05$.

\section{RESULTS}

\section{Experiment 1}

All micropropagated plants were of similar size when transplanted from weaning conditions. Growth of non-mycorrhizal plants was similar in the two disinfected soils (figs 1 and 2). Micropropagated plants responded to inoculation with the two mycorrhizal fungi, and stem height of inoculated plants was significantly greater than that of control plants at 6 and 10 weeks in E1D and E2D, respectively (fig 1 ). This beneficial effect of inoculation persisted up to 12 weeks after transfer into the disinfected soils.

Plants inoculated with $G$ intraradices or $G$ caledonium and transferred to E1D and E2D also had greater shoot dry mass and stem diameter than in the control plants after 12 weeks' growth (fig 2A, B). Again, mycorrhizal effects were more important in the soil E1D than E2D, and the main effect of $G$ intraradices concerned shoot dry mass whereas that of $G$ caledonium was on stem diameter. Both fungi had a positive effect on the number of leaves as compared to control plants (fig $2 \mathrm{C}$ ), but differences between soils and fungal species were less pronounced than for the other growth parameters. Soil type affected the development of mycorrhizal plants and there were some significant $(P<0.05)$ differences between fungus/soil combinations. $G$ intraradices-infected $P$ avium had a significantly higher shoot dry mass on E1D than on E2D, and $G$ intraradices was overall more effective than $G$ caledonium in improving $P$ avium growth on E2D. Plant growth improvements by either fungus were related to high levels of mycorrhizal colonization (table I). However, some differences were observed in mycorrhiza development between the two soil types: mycorrhizal intensity
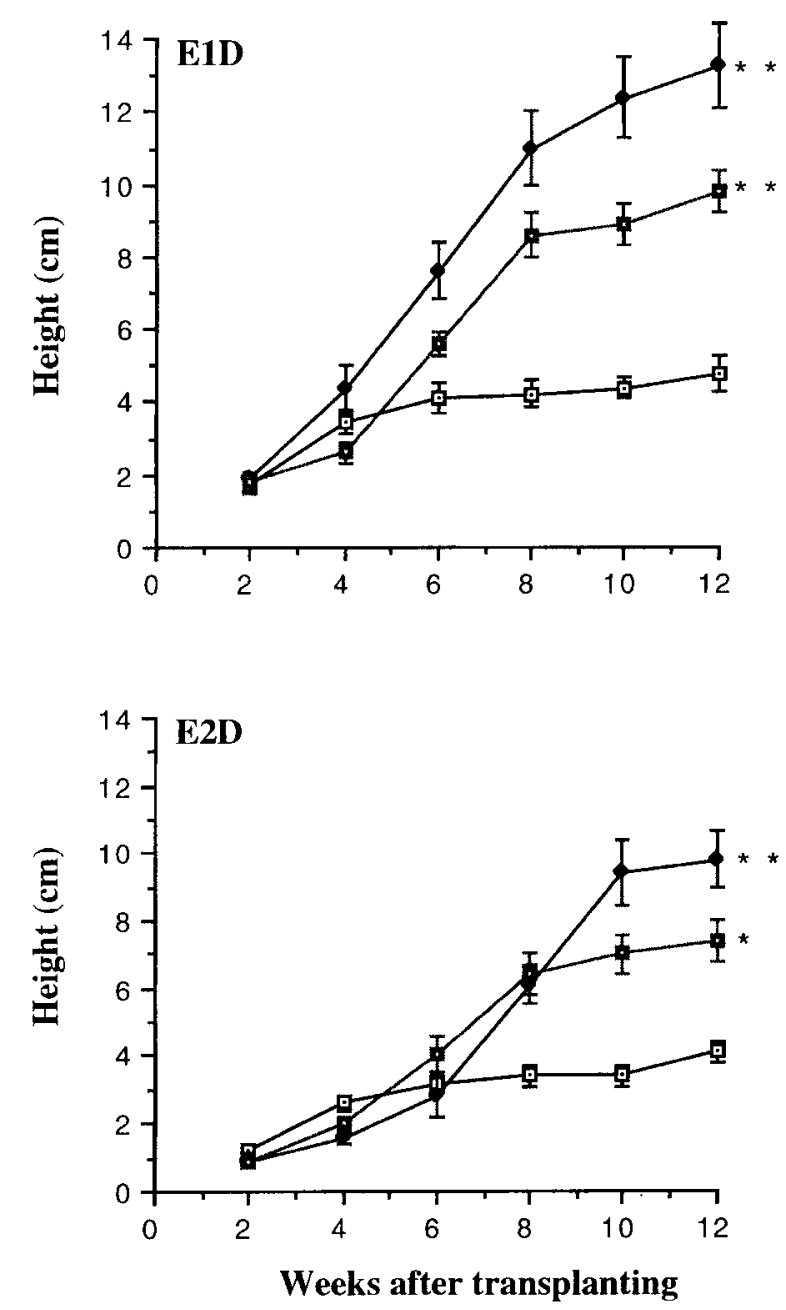

Fig 1. Height of Prunus avium clone 227, uninoculated ( $\square$ ) or preinoculated with Glomus intraradices $(\downarrow)$ or Glomus caledonium ( $\square$ ), in two disinfected soils, E1D and E2D. Vertical bars represent standard errors of the mean. Growth curves of inoculated plants with one or two asterisks are significantly different from the uninoculated plants at $P<0.05$ or $P<0.01$, respectively. 

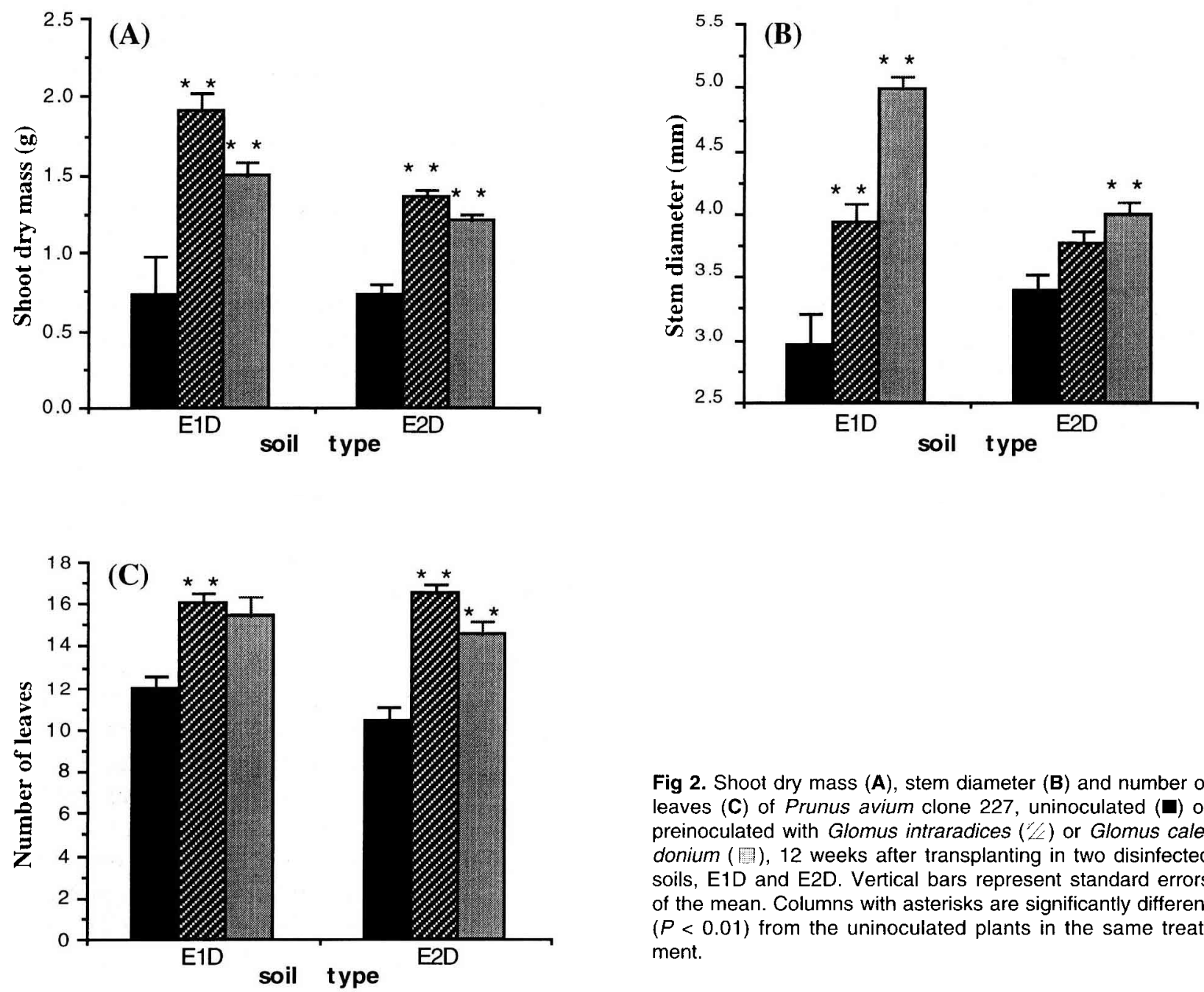

Fig 2. Shoot dry mass (A), stem diameter (B) and number of leaves (C) of Prunus avium clone 227, uninoculated ( $\boldsymbol{D}$ ) or preinoculated with Glomus intraradices ( donium (圈), 12 weeks after transplanting in two disinfected soils, E1D and E2D. Vertical bars represent standard errors of the mean. Columns with asterisks are significantly different $(P<0.01)$ from the uninoculated plants in the same treatment.

Table I. Mycorrhizal colonization of micropropagated Prunus avium clone 227 plants, preinoculated or not with Glomus intraradices or $G$ caledonium 12 weeks after transfer into the disinfected or undisinfected soils, E1 and E2.

Uninoculated $P$ avium

$\mathrm{F} \%$

$\mathrm{M} \%$

$P$ avium inoculated with $G$ intraradices

$$
\mathrm{F} \%
$$

$\mathrm{M} \%$

$P$ avium inoculated with $G$ caledonium

$$
\mathrm{F} \%
$$

$\mathrm{M} \%$

$\begin{array}{ll}- & 97^{a b} \\ - & 70^{a}\end{array}$

$99 \mathrm{~b}$

$66^{a}$

92

69 a

$95^{b}$

67 a
$99 \mathrm{~b}$

$68^{a}$ $88^{b}$

54 a

$87^{b}$

$48^{\text {a }}$

94 bc

$55^{a}$

F\%: frequency of root colonization; M\%: intensity of root colonization. For each soil, $\mathrm{F} \%$ and $\mathrm{M} \%$ values followed by the same letter are not significantly different at $P<0.05$. 
for the two fungi was significantly reduced $(P<$ 0.01 ) in E2D, as compared to E1D, and only mycorrhizal frequency of $G$ caledonium was similar in the two soils.

The interest of early mycorrhizal inoculation for $P$ avium growth in the two undisinfected soils was assessed by comparing growth of plants precolonized by $G$ intraradices or $G$ caledonium before transplanting with those only colonized by indigenous fungi after transplanting. Growth of $P$ avium colonized by indigenous fungi was similar in the two undisinfected soils (figs 3 and 4). Growth parameters were not particularly different from non-mycorrhizal plants in the disinfected soils (figs 2 and 4 ) except for an increase in stem diameter, even though the number of mycorrhizal
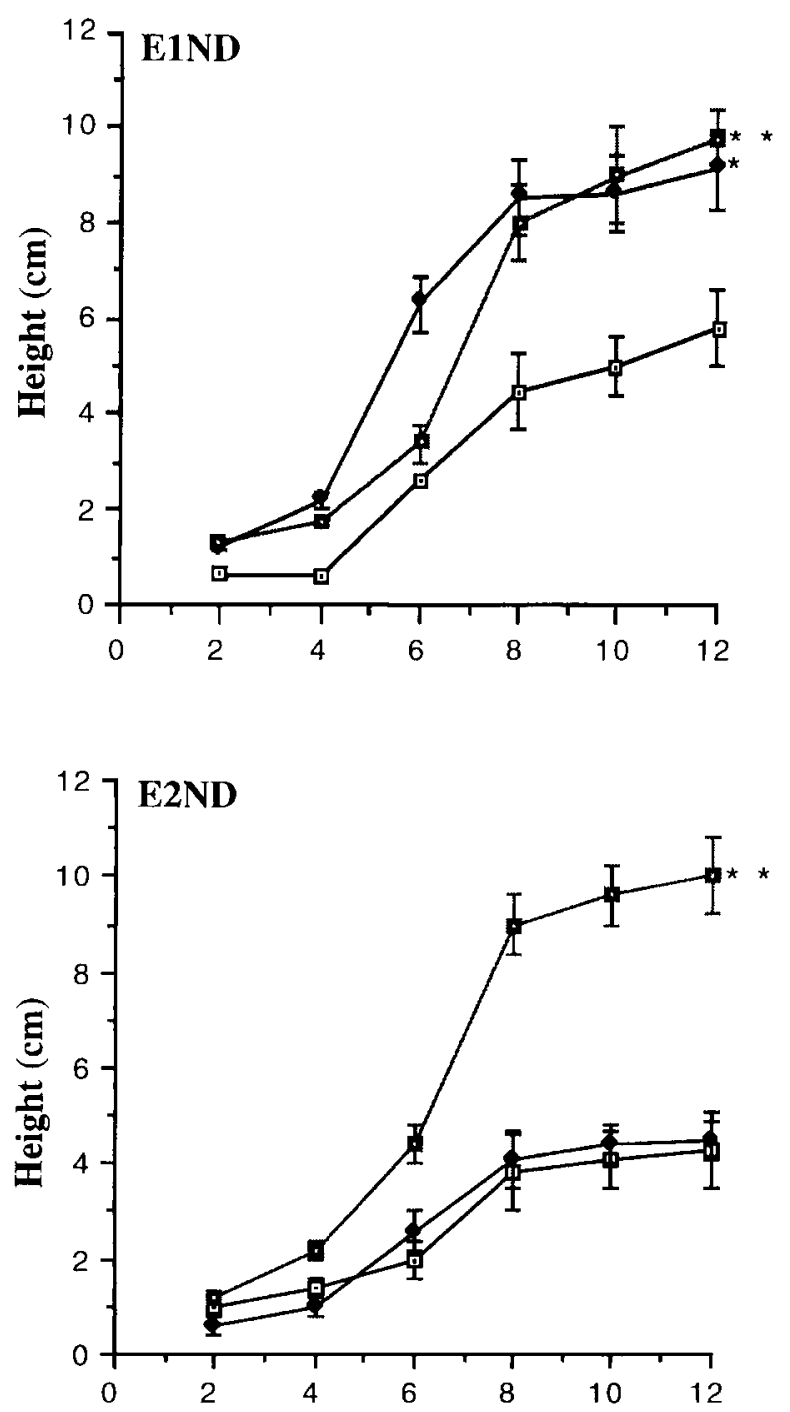

Fig 3. Plant height of Prunus avium clone 227, uninoculated (D) or preinoculated with Glomus intraradices $(4)$ or Glomus caledonium ( $\mathbf{\square})$, in two undisinfected soils, E1ND or E2ND. Vertical bars represent standard errors of the mean. Growth curves with one or two asterisks are significantly different from the uninoculated plants at $P<0.05$ or $P<0.01$, respectively. propagules and overall levels of mycorrhizal colonization were high in both soils (table I), indicating that the indigenous fungal populations were not efficient.

Preinoculated plants showed a significant increase in growth as compared to control plants in the soil E1ND, and this was observed for all parameters except stem diameter in plants preinoculated with $G$ caledonium (figs 3 and $4 \mathrm{~A}-$ C). In the soil E2ND, growth responses only occurred in plants precolonized by $G$ caledonium, but again the effect on stem diameter was not significant. Growth of $G$ caledonium-colonized plants did not differ greatly in the disinfected (fig 2) or undisinfected soils (fig 4). However, no growth improvement was observed for $G$ intraradices-colonized $P$ avium on E2ND (figs 3 and $4 A, C$ ), contrary to the beneficial effects of preinoculation seen in the same disinfected soil (E2D).

Overall levels of mycorrhizal colonization in the two undisinfected soils were high in $P$ avium pre-colonized by $G$ caledonium or $G$ intraradices, but they were not significantly different from those in the uninoculated control plants (table I). This was linked to the high mycorrhizal potential of these soils. Moreover, as for the disinfected soils, undisinfected $E 1$ soil gave significantly higher values $(P<0.05)$ for mycorrhizal frequency and intensity (99 and 66-68\%, respectively) than undisinfected E2 soil (87-94 and $48-55 \%$, respectively); however, it was not possible to differentiate between mycorrhizal colonization by indigenous fungi and that of the introduced Glomus species.

\section{Experiment 2}

Micropropagated plants of the three clones F12$1,4878 \times 2620$ and $2680 \times 1923$ were of similar size at outplanting from in vitro into the $G$ mosseae-inoculated soil mixture. Beneficial effects of $G$ mosseae on plant height were already seen at 4 weeks after outplanting in all the mycorrhizal $P$ avium clones, as compared to non-mycorrhizal plants (fig 5). Growth improvement was more than $50 \%$ at 6 weeks after inoculation of the three clones, and the clone F12-1 was more responsive to $A M$ than the other two clones. At 6 weeks, mycorrhizal F12-1 showed a $70 \%$ height increase over non-mycorrhizal plants, as compared to about $50 \%$ for the clones $4878 \times 2620$ and $2680 \times 1923$; however, at 10 weeks, differences in mycorrhizal growth 

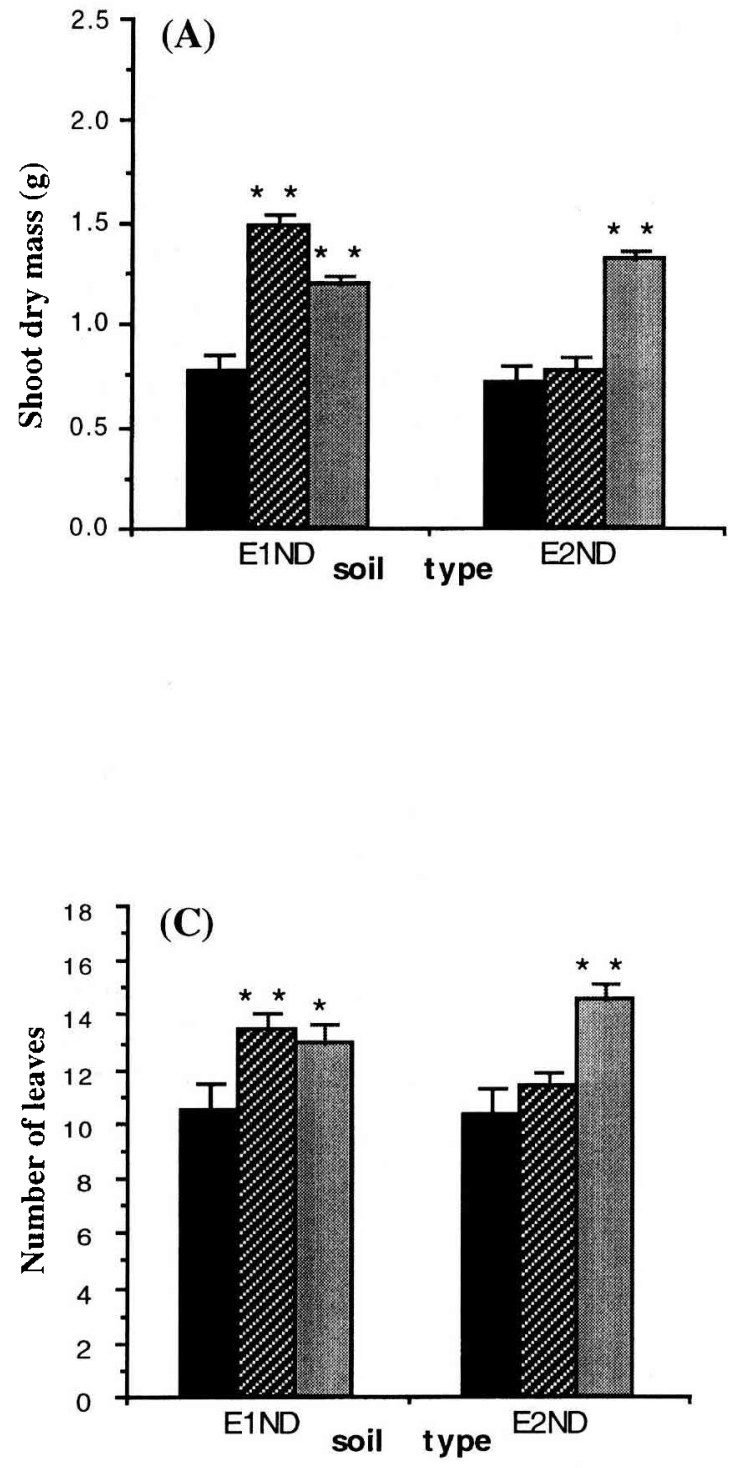

responses between $\mathrm{F} 12-1$ and $4878 \times 2620$ plants were less (57.8 and $66.4 \%$, respectively). Moreover, growth of the shoot apex was blocked in an important proportion of uninoculated plants from the three $P$ avium clones (table II). This phenomenon was negligible in the $G$ mosseaecolonized clones F12-1 and 4878x2620 and was significantly reduced in the mycorrhizal clone $2680 \times 1923$.

The mycorrhizal growth effects on the $P$ avium clones were related to an important development of $G$ mosseae in the root systems (fig 5). However, clonal differences were observed and mycorrhizal colonization was lower in the clones $4878 \times 2620$ and $2680 \times 1923$ than in F12-12 weeks after $G$ mosseae. These differences were maintained up to 4 weeks, then tended to disappear between the clones $\mathrm{F}_{12-1}$ and $4878 \times 2620$ (fig 5).

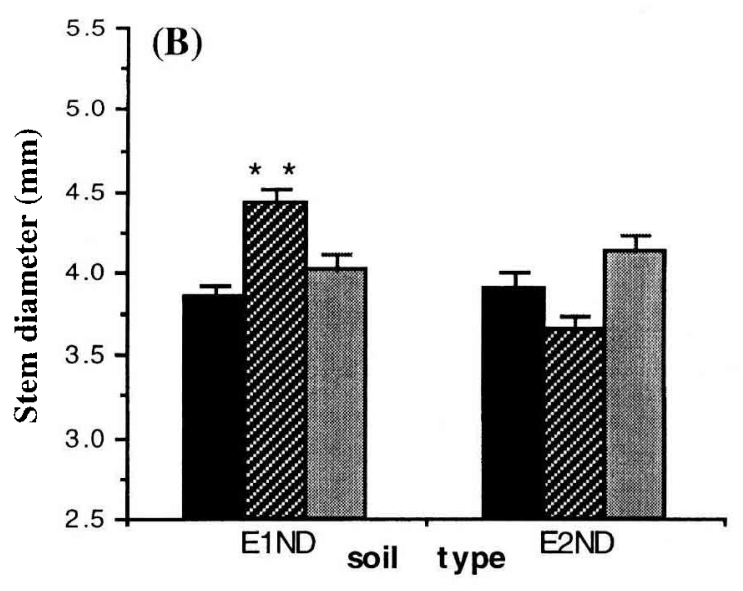

Fig 4. Shoot dry mass (A), stem diameter (B) and number of leaves (C) of Prunus avium clone 227, uninoculated (D) or preinoculated with Glomus intraradices ( 4 ) or Glomus cale-

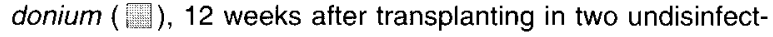
ed soils, E1ND or E2ND. Vertical bars represent standard errors of the mean. Columns with one or two asterisks are significantly different from the uninoculated plants in the same treatment at $P<0.05$ or $P<0.01$, respectively.

Table II. Percentage of plants with a blocked shoot apex in three uninoculated (NM) and Glomus mosseae-inoculated (+Gm) Prunus avium clones, 4 weeks after the weaning period.

Plants with a blocked apex (\%)

$\begin{array}{lr}P \text { avium clone } \mathrm{F} 12-1 & \\ \quad \mathrm{NM} & 37.0^{\mathrm{a}} \\ +\mathrm{Gm} & 0.0^{\mathrm{c}} \\ \text { Pavium clone } 4878 \times 2620 & \\ \quad \mathrm{NM} & 31.5^{\mathrm{a}} \\ +\mathrm{Gm} & 3.0^{\mathrm{b}} \\ \begin{array}{l}P \text { avium clone } 2680 \times 1923 \\ \text { NM }\end{array} & \\ +\mathrm{Gm} & 48.2^{\mathrm{a}} \\ & 6.5^{\mathrm{b}}\end{array}$

Values with the same letter are not significantly different $(P<$ 0.05). 


\section{Experiment 3}

The intensity of mycorrhizal colonization in $P$ avium clone $\mathrm{F} 12-1$ was $73.6 \%$ ( $\pm 3 \%$ ) of the root system cortex, 3 weeks after $G$ mosseae inoculation and when the plants were inoculated with $P$ cinnamomi. Shoot and root development of mycorrhizal $P$ avium, whether inoculated or not with the pathogen, was always greater than that of non-mycorrhizal plants (fig 6). $P$ cinnamomi did not significantly affect fresh shoot mass of nonmycorrhizal or mycorrhizal plants at 2 and 4 weeks after pathogen inoculation (fig 6A). In contrast, root development was affected by $P$ cinnamomi (fig 6B), although no necroses were observed in roots of either non-mycorrhizal or mycorrhizal plants inoculated with the pathogen. Root fresh mass of non-mycorrhizal plants inoculated with $P$ cinnamomi was significantly decreased as compared to control plants at 2 and 4 weeks after pathogen inoculation (fig 6B). Such a reduction in biomass was not observed for mycorrhizal root systems inoculated with $P$ cinnamomi, and the pathogen had no effect on mycorrhizal development (data not shown).

\section{DISCUSSION}

The present observations show that early AM development has a beneficial effect on the growth of micropropagated $P$ avium, as has been reported for other micropropagated plant species (Ravolanirina et al, 1989a; Branzanti et al, 1992; Berta et al, 1995). Moreover, mycorrhizal effects on $P$ avium plants can be optimized through careful selection of combinations of AM fungal strain, soil type and plant clone. $P$ avium plants colonized by $G$ intraradices (LPA8) and $G$ caledonium (BEG20) had better growth than nonmycorrhizal plants in both the disinfected soils tested. However, mycorrhizal development was slightly lower in E2D soil than E1D soil, suggesting that it was influenced by the different chemical characteristics of the two soils. Inoculation of micropropagated $P$ avium with the two AM fungi prior to transplanting gave different results in the undisinfected soils, where indigenous populations of AM fungi were high and infective but not efficient in stimulating plant growth. Preinoculation with either $G$ caledonium or $G$ intraradices had beneficial effects on growth of

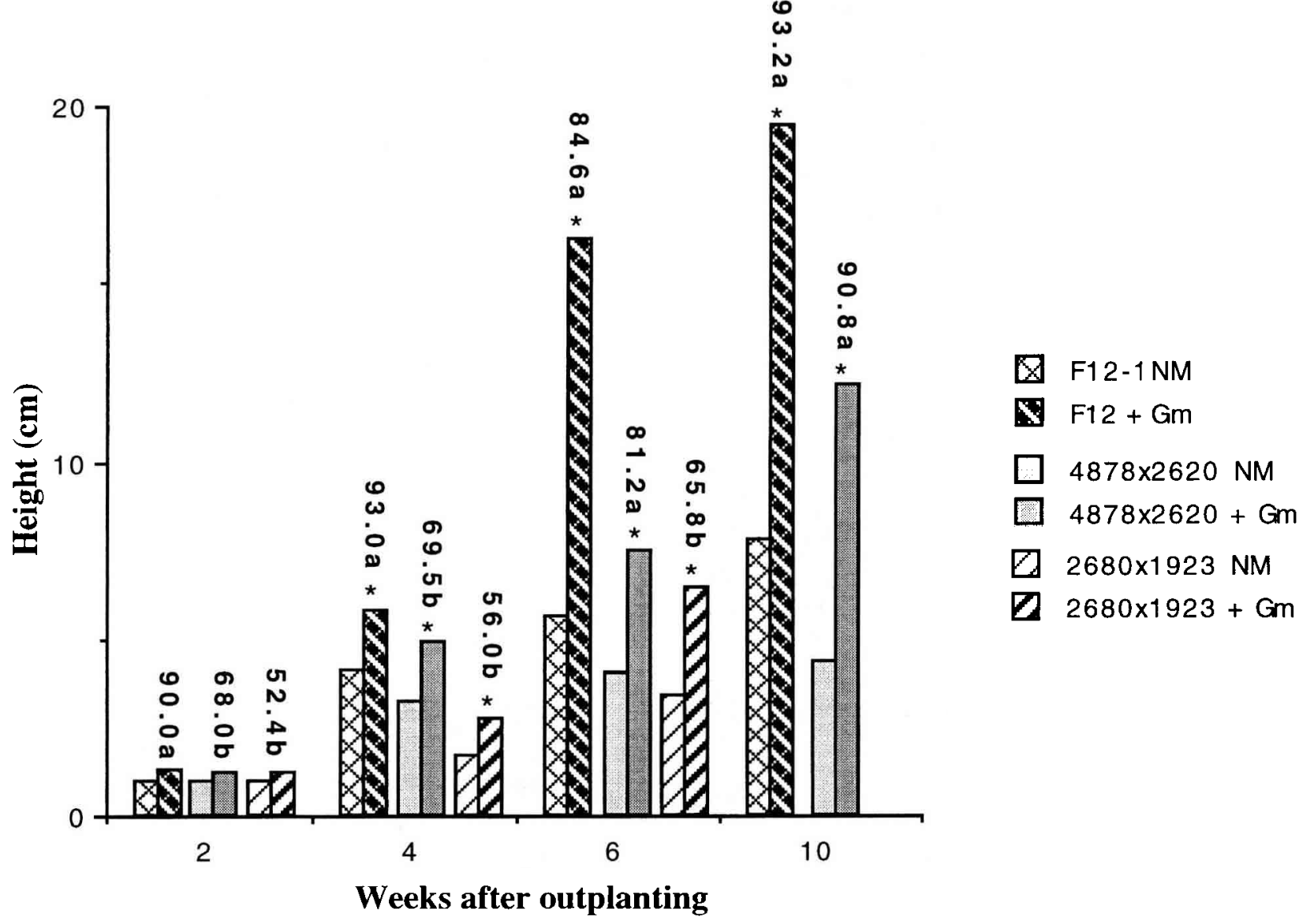

Fig 5. Growth of three Glomus mosseae-inoculated (+ Gm) and uninoculated (NM) Prunus avium clones (F12-1, 4878x2620, $2680 \times 1923)$ and evaluation of mycorrhizal colonization (M\%). For each week, values of mycorrhizal colonization shown above columns and followed by a different letter are significantly different at $P<0.05$. Values in columns with one asterisk are significantly different from uninoculated plants in the same treatment at $P<0.05$. 
$P$ avium microplants in the undisinfected soil $E 1$, as compared with plants colonized only by the indigenous AM fungi of this soil.

In contrast, in the undisinfected soil E2, only $G$ caledonium had consistent positive effects on plant growth in the presence of the indigenous AM fungal population, illustrating the competitive ability of this fungus vis-à-vis the $A M$ fungi in this soil. $G$ intraradices had no effect on plant growth in this soil, suggesting that it could not compete with the indigenous AM fungal population.
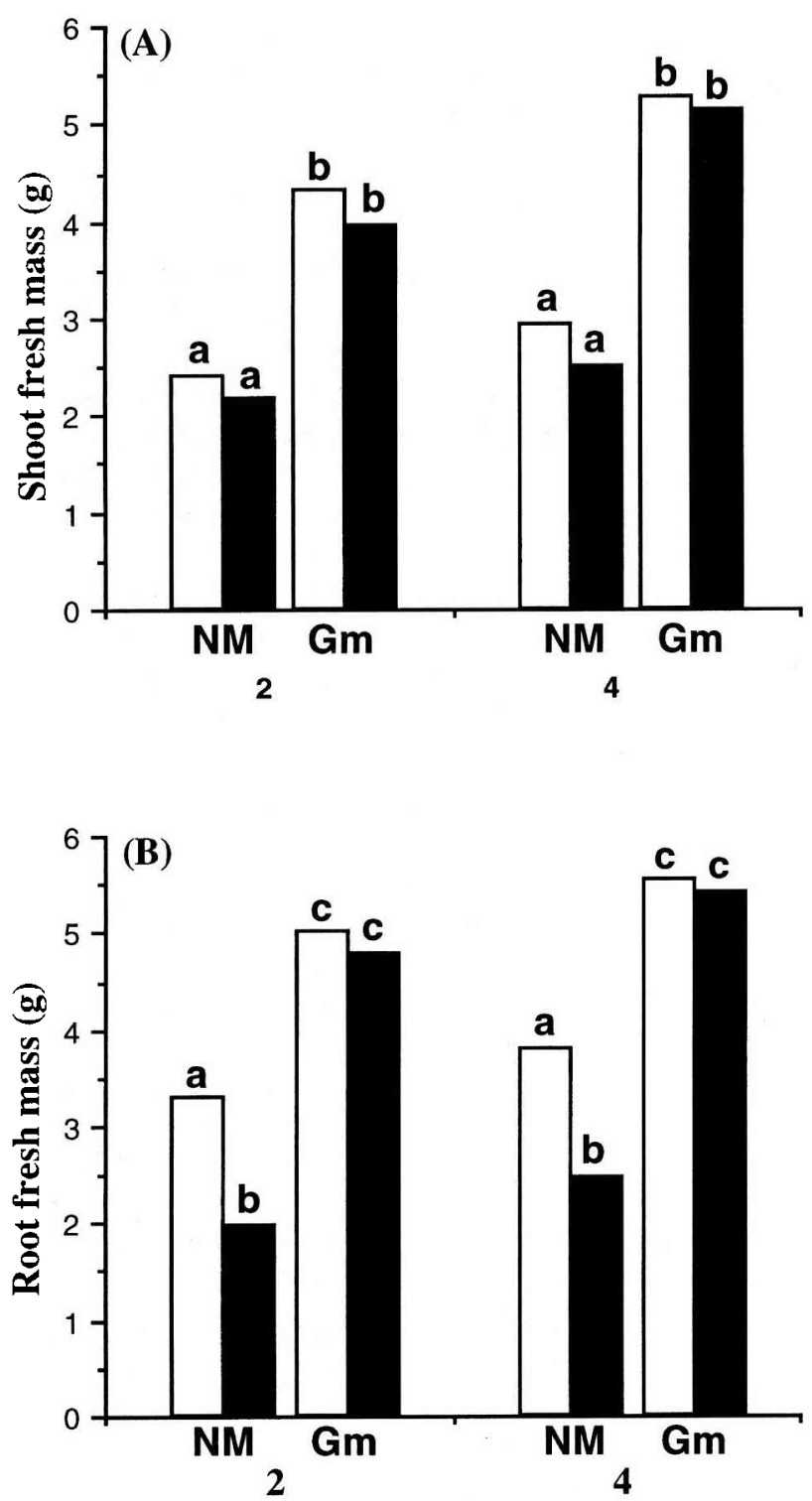

Weeks after $P$. cinnamomi inoculation

Fig 6. Shoot (A) and root (B) fresh mass of non-mycorrhizal (NM) and mycorrhizal (Gm) Prunus avium clone F12-1, uninoculated $(\square)$ or inoculated $(\square)$ with $P$ cinnamomi 3 weeks after Glomus mosseae inoculation, and harvested 2 or 4 weeks after $P$ cinnamomi inoculation. For each week, values in columns with the same letter are not significantly different $(P<0.05)$.
It can be concluded from this study that in soils containing infective but inefficient AM fungal populations, growth of micropropagated $P$ avium can be considerably improved by preinoculation with effective AM fungi adapted to the soil type. In the present case, $G$ caledonium (BEG20) should be used to improve growth of $P$ avium in the $\mathrm{E} 2$ soil, while $G$ intraradices (LPA8) is better adapted for plant production in the $\mathrm{E} 1$ soil. Further studies are necessary to ensure that these beneficial mycorrhizal effects are maintained, and that root colonization by the introduced fungus persists after outplanting into field conditions. Such investigations are presently hampered by the difficulty in distinguishing between different AM fungi within roots, and they emphasize the need to develop suitable immunological or nucleic acid probes to monitor control-inoculated efficient fungi after outplanting into undisinfected soils (Cordier et al, 1996a; Zézé et al, 1996).

Clonal variations in AM development and mycorrhizal responsiveness to $G$ mosseae were observed in the micropropagated $P$ avium, as has been reported by Guillemin et al (1992) between different micropropagated pineapple varieties. This variability in $P$ avium clones was largely related to the intensity of mycorrhizal development. However, blocked apical shoot growth was also frequent in control plants after transplanting, while this did not occur in the mycorrhizal $P$ avium microplants. This phenomenon has also been observed for other woody plants like micropropagated fruit rootstocks (Fortuna et al, 1992; Sbrana et al, 1994), pear tree and walnut (B Blal, personal communication). Consequently, the important differences in height between mycorrhizal and non-mycorrhizal $P$ avium also resulted from differences in the growth behaviour of the plants. Moreover, it has already been shown that the efficacy of AM is not necessarily directly linked to the level of root colonization but can also depend on the ability of fungal strains to transfer mineral nutrients from the soil to the host plant (Smith and GianinazziPearson, 1988; Guillemin et al, 1992), or their effects on hormone balance in mycorrhizal plants (Allen et al, 1982; Trotta et al, 1991).

AM fungi can also have an impact on plant growth through their role as biocontrol agents against certain root pathogens, including Phytophthora (Bärtschi et al, 1981; Guillemin et al, 1994; Cordier et al, 1996b). The pathogen $P$ cinnamomi did not cause negative effects on root fresh mass of $P$ avium plants precolonized by $G$ mosseae, whereas a depression in root growth was observed in $P$ cinnamomi-infected 
non-mycorrhizal plants. Further studies are necessary to better understand and more precisely explain mechanisms involved in this phenomenon. In tomato, bioprotection by AM against $P$ parasitica is linked to a reduction in the spread of the pathogen within mycorrhizal root systems and to a resistance of arbuscule-containing cells (Cordier et al, 1996b). This may be related to the activation of defence responses in host tissues (Gianinazzi, 1991; Benhamou et al, 1994; C Cordier, S Gianinazzi, V Gianinazzi-Pearson, unpublished results), or to the expression of certain defence-related genes induced by the presence of the symbiotic fungus in arbuscule-containing cells (Gianinazzi-Pearson et al, 1992, 1996; Harrison and Dixon, 1994; Lambais and Mehdy, 1995; Blee and Anderson, 1996).

\section{ACKNOWLEDGMENTS}

Part of this work was financed by the EU in the project 'Biological control of root pathogens by VA mycorrhizas: research into mechanisms involved' (AIR3 contract no CT 94-0809).

\section{REFERENCES}

Allen MF, Moore TS, Christensen M (1982) Phytohormone changes in Bouteloua gracilis by vesicular-arbuscular mycorrhizae. II. Altered levels of gibberellin-like substances and abscissic acid in the host plant. Can J Bot 60, 468-471

Azcón-Aguilar C, Barea JM (1997) Arbuscular mycorrhizas and biological control of soil-borne plant pathogens. An overview of the mechanisms involved. Mycorrhiza (in press)

Bärtschi H, Gianinazzi-Pearson V, Vegh I (1981) Vesicular-arbuscular mycorrhiza formation and root rot disease (Phytophthora cinnamomi) development in Chamaecyparis lawsoniana. Phytopathol Z 102, 213-218

Benhamou N, Fortin JA, Hamel C, St Arnaud M, Shatilla A (1994) Resistance responses of mycorrhizal $\mathrm{Ri} \mathrm{T}$-DNA-transformed carrot roots to infection by Fusarium oxysporum $f \mathrm{sp}$ chrysanthemi. Phytopathology 84, 958-968

Berta G, Trotta A, Hooker J, Munro M, Atkinson D, Giovannetti M, Marini S, Loreti F, Tisserant B, Gianinazzi-Pearson V, Gianinazzi S (1995) The effects of arbuscular mycorrhizal infection on plant growth, root system morphology and soluble protein content in Prunus cerasifera L. Tree Physiol 15, 281-293

Bethlenfalvay GJ, Linderman RG (1992) Mycorrhizae in Sustainable Agriculture. ASA Special Publication no 54, American Society of Agronomy, Madison, WI, USA

Blee KA, Anderson AJ (1996) Defense-related transcript accumulation in Phaseolus vulgaris $\mathrm{L}$ colonized by the arbuscular mycorrhizal fungus Glomus intraradices Schenck \& Smith. Plant Physiol 110, 675-688

Branzanti B, Gianinazzi-Pearson V, Gianinazzi S (1992) Influence of phosphate fertilization on the growth and nutrient status of micropropagated apple infected with endomycorrhizal fungi during the weaning stage. agronomie 12, 841-845

Cordier C, Gianinazzi S, Gianinazzi-Pearson V (1996a) An immunological approach for study of spatial relationships between mycorrhizal fungi in planta. In: Mycorrhizas in Integrated Systems from Genes to Plant Development (C Azcón-Aguilar, JM Barea, eds), European Commission, EUR 16728, Luxembourg, 25-34

Cordier C, Gianinazzi S, Gianinazzi-Pearson V (1996b) Colonisation patterns of root tissues by Phytophthora nicotianae var parasitica related to reduced disease in mycorrhizal tomato. Plant Soil $185,223-232$

Douds DD, Chaney WR (1986) The effect of high nutrient addition upon seasonal patterns of mycorrhizal development, host growth, and root phosphorus and carbohydrate content in Fraxinus pennsylvanica Marsh. New Phytol 103, 91-106

Fortuna P, Citernesi A, Morini S, Giovannetti M, Loreti $F$ (1992) Infectivity and effectiveness of different species of arbuscular mycorrhizal fungi in micropropagated plants of $\mathrm{Mr} \mathrm{S} 2 / 5$ plum rootstock. agronomie 12, 825-829

Gianinazzi S (1991) Vesicular-arbuscular (endo-) mycorrhizas: cellular, biochemical and genetic aspects. Agric Ecosyst Environ 35, 105-119

Gianinazzi S, Trouvelot A, Gianinazzi-Pearson V (1983) Les endomycorhizes : importance dans la croissance et le développement des arbres fruitiers. Fruits 38, 659-662

Gianinazzi-Pearson V, Tahiri-Alaoui A, Antoniw JF, Gianinazzi S, Dumas-Gaudot E (1992) Weak expression of the pathogenesis related PR-b1 gene and localisation of related protein during symbiotic endomycorrhizal interactions in tobacco roots. Endocytobiosis Cell Res 8, 177-185

Gianinazzi-Pearson V, Dumas-Gaudot E, Gollotte A, Tahiri-Alaoui A, Gianinazzi S (1996) Cellular and molecular defence-related root responses to invasion by arbuscular mycorrhizal fungi. New Phytol $133,45-57$

Guillemin JP, Gianinazzi S, Gianinazzi-Pearson V (1991) L'endomycorhization de vitroplants d'Ananas comosus : mise en évidence d'un effet mycorhizien. Fruits 46, 355-358

Guillemin JP, Gianinazzi S, Trouvelot A (1992) Screening of VA endomycorrhizal fungi for establishment of micropropagated plants. agronomie 12 , 831-836 
Guillemin JP, Gianinazzi S, Gianinazzi-Pearson V, Marchal J (1994) Contribution of arbuscular mycorrhizas to biological protection of micropropagated pineapple (Ananas comosus (L) Merr) against $P$ cinnamomi Rands. Agri Sci Finn 3, 241-251

Harrison MJ, Dixon RA (1994) Spatial patterns of expression of flavonoid/isoflavonoid pathway genes during interactions between roots of medicago truncatula and the mycorrhizal fungus Glomus versiforme. Plant J 6, 9-20

Hayman DS (1974) Plant growth responses to vesicular-arbuscular mycorrhiza. VI. Effect of light and temperature. New Phytol 73, 71-80

Hewitt EJ (1966) Sand and water culture methods used in the studies of plant nutrition. In: Technical communication, Commonwealth Agricultural Bureau, London, UK, 22, 430-434

Lambais MR, Mehdy MC (1995) Differential expression of defense-related genes in arbuscular mycorrhiza. Can J Bot 73 (Suppl 1), S533-S540

Linderman LC (1994) Role of VAM fungi in biocontrol. In: Mycorrhizae and Plant Health (FL Pfleger, RG Linderman, eds), The American Phytopathological Society Press, St Paul, MN, USA, 1-27

Lovato PE, Hammatt NH, Gianinazzi-Pearson V, Gianinazzi S (1994) Mycorrhization of micropropagated mature wild cherry (Prunus avium L) and common ash (Fraxinus excelsior L). Agric Sci Finn 3, 297-301

Lovato PE, Gianinazzi-Pearson V, Trouvelot A, Gianinazzi S (1996) The state of art of mycorrhizas and micropropagation. Adv Hort Sci 10, 46-52

Plee J (1986) L'endomycorhization contrôlée du merisier. Rapport de dîplome d'ingénieur, Lille, France

Ponders F Jr (1984) Growth and mycorrhizal development of potted white ash and black walnut fertilized by two methods. Can J Bot $62,509-512$
Pons F, Gianinazzi-Pearson V, Gianinazzi S, Navatel JC (1983) Studies of VA mycorrhizae in vitro: mycorrhizal synthesis of axenically propagated wild cherry (Prunus avium L) plants. Plant Soil 71, 217 221

Ravolanirina F, Blal B, Gianinazzi S, GianinazziPearson V (1989a) Mise au point d'une méthode rapide d'endomycorhization des fruits micropropagés. Fruits 44, 165-170

Ravolanirina F, Gianinazzi S, Trouvelot A, Carre M (1989b) Production of endomycorrhizal explants of micropropagated grapevine rootstocks. Agric Ecosyst Environ 29, 323-327

Sbrana C, Giovannetti M, Vitagliano C (1994) The effect of mycorrhizal infection on survival and growth renewal of micropropagated fruit rootstocks. Mycorrhiza 5, 153-156

Smith SE, Gianinazzi-Pearson V (1988) Physiological interactions between symbionts in vesicular-arbuscular mycorrhizal plants. Annu Rev Plant Physiol Plant Mol Biol 39, 221-244

Trotta A, Berta G, Fusconi A, Scannerini A (1991) Root development in a VA mycorrhiza, as related to phosphorus nutrition. In: Abstracts of the 3rd ISRR Symposium (Kutschera, ed), Vienna, Austria, 134

Trouvelot A, Kough JL, Gianinazzi-Pearson V (1986) Mesure du taux de mycorhization VA d'un système radiculaire. Recherche de méthodes d'estimation ayant une signification fonctionnelle. In: Physiological and Genetical Aspects of Mycorrhizae (V Gianinazzi-Pearson, S Gianinazzi, eds), INRA, Paris, France, 217-221

Zézé A, Hosny M, Gianinazzi-Pearson V, Dulieu H (1996) Characterization of a highly repeated DNA sequence (SC1) from the arbuscular mycorrhizal fungus Scutellospora castanea and its detection in planta. Appl Environ Microbiol 62, 2443-2448 